\title{
Sanctification of Water among the Population of the Khorezm Oasis
}

\author{
Abidova Zaynab Kadirberganovna \\ Head of the Department "Social sciences", Urgench Branch of the Tashkent Medical \\ Academy Urgench, Khorezm, Uzbekistan. ORCID: oooo-0oo1-5440-4041. \\ Email: zaynab_74_2011@mail.ru
}

\begin{abstract}
Water holds a specific place in life of the people of the Khorezm oasis located in the lower reaches of the deep Amu Darya River which are between the Kara-Kum and Kyzyl-Kum Deserts. This article is devoted to a study of natural places of a pilgrimage connected with the water cult elements of Khwarezm. The remnants of ancient religions are studied and analyzed and found that the rites that are connected with water are traced in the Khorezm oasis. Special attention is paid to the history of studying of genesis and evolution of a cult of water of the Khorezm hagiology and their roles in life of inhabitants of the Khorezm oasis. This can be an important step towards the of revival of spiritual and cultural life of the Uzbek people.
\end{abstract}

Keywords: water, cult, places of a pilgrimage, legend, ceremony, Hubbi, Amu Darya.

\section{Introduction}

Khorezm, ${ }^{*}$ the most ancient cultural oasis located in lower reaches of the deep Amu Darya River and between the deserts in the north of Uzbekistan. Khorezm is considered as one of the centers of the most ancient civilization. Khorezm is bordered from the North with the sea, from the East and the southwest with the Kara-Kum and Kyzyl-Kum Deserts [2., P.23]. Water holds a specific place in life of the people of the Khorezm oasis located in the lower reaches of the deep Amu Darya River which are between the Kara-Kum and Kyzyl-Kum Deserts. Honoring natural objects in Khorezm is not so strongly expressed in comparison with other areas of Central Asia.

There is saying in Khorezm and it is very much appreciated "There is no life without water, there is no pleasure without effort". Because the life of the people of the Khorezm oasis, engaged in agriculture as well as in some other regions of the ancient east depended first of all on the existence of water sources and artificial irrigation [3., P.39]. Geographical, cultural and economic conditions of the Khorezm oasis ensured the central place in religious beliefs, since from ancient times it was occupied by a cult of water elements between deserts. It was reflected in beliefs of the Khorezm oasis and could receive independent value in the developed pantheon, the images of goddesses of fertility representing water elements.

According to ancient representations, the basis of the universe was made by four sacred elements - the earth, water, air and fire. Water was esteemed as one of sources and basis of live. In Avesta

(c) AesthetixMS 2020. This Open Access article is published under a Creative Commons Attribution Non-Commercial 4.o International License (http://creativecommons.org/licenses/by-nc/4.o/), which permits non-commercial re-use, distribution, and reproduction in any medium, provided the original work is properly cited. For citation use the DOI. For commercial re-use, please contact editor@rupkatha.com. 
there is a deity of water elements and the rivers Ardvisura - Anakhita to whom the special anthem is devoted [4., P.45]. The people of Khwarezm living between deserts considered water sacred and tried to keep waters of the rivers, channels and wells pure. The concept of special sacral purity of water elements can be detected in those ritualistic measures with which they tried to protect water from all forms of pollution. Of course it is impossible to say that the channels and reservoirs were in an ideal order earlier. But there were moments when the whole ritual of purification of water in the well, flowing or standing in reservoirs was required. It occurred when in water for any of several reasons there was a dead body of the person, the dog or other animal [5., P.140]. People of an oasis held off those "impure" people and pets at least 15 meters far from water [FDA$1]$.

In the Central Asia including, Khorezm there are "sacred" rivers, channels, sources, and wells which are usually located about mazars (funerals) meet. According to a number of the field researches carried out by us, one may say that many of these funeral sanctuaries arose about water sources [FDA-2].

\section{Sacred rivers}

All know that water of the Amu Darya River was of great importance for the life of the Khorezm oasis located between deserts. Ancient Greek authors called Amu Darya "Oksus" or "Oks", and the Arab writers by "Zhaykhun". As there would be no Egypt without the Nile, also there would be no Khorezm without the Amu Darya. As the famous geographer and the historian of the Middle Ages al Istakhri writes, Khorezm is the country which has managed to receive all advantage of Zhaykhun wholly [1., P.29]. Oasis is the true creation of Amu Darya [2.,P.22-23].The wellbeing of the Khorezm population is closely connected with the river and therefore the Amu Darya was the subject to worship. There was a gratitude for life-giving force, and fear of blind destructive elements of the 'mad' river. The vital river has a rich and interesting story; its manifestations are shrouded in a crape of written legends and fairy tales and are sung in songs and national poems. The awful and whimsical nature of the Amu Darya became the reason of emergence of various national myths and legends. One of the widespread legends connected with deyish (washing off of the coast) is a legend of spiteful spirits. According to the legend, the evil and faceless ghosts of an aranglar (idea of their plurality is characteristic) live in the depth of the Amu Darya and control its flow. They can change a watercourse willingly, create deyish, wash away coast, heat the ships, create a flood, and destroy the cities and villages [1., P.36].

However, in representations about the aranglar (ghosts) also the opposite relation to them is traced. In Muslim interpretation and in many information it is said that they "bring benefit to people" and "the beings loved by god". Aranglar are the invisible shades that inhabit all around the world. They appear in the desert, but also in these beliefs they don't lose some touch with elements of water: "... if the person gets lost in the desert and is parched with thirst, aranglar give him water to drink to" [5., P.236-237]. Different superstitions, traditions, and customs appeared on the basis of similar legends. For example, following those traditions the ships began to install the legendary symbols on a nasal part of the ship going across the Amu Darya.

Hubbi's cult was the patron of water of the Amu Darya. In the Khorezm hagiology it holds a specific place, and is traced in traditions of honoring of the water elements. Studying the history of an irrigation of ancient Khorezm the academician Ya. G. Gulyamov has written down a number of legends connected with the Amu Darya retold by old residents. Very curious legend of Hubbi the young man of the patron of the river tells the old boatman: 
"Long before Ferydoon and even Dzhemshid [7., P.32-33] on this river there lived a young man who became the master of the river. His name was Hubbi, he ate fish: having caught fish from water, he held it up to the sun, and fish fried. During seven hundred years while he was on Amu Darya, there was no evil ghost and even mosquitoes on the river. In Jamsheed's reign Hubbi disappeared [7., P.32-33]. They believed that he was kidnapped by the Beauty, the ruler of the heavenly seas. After his disappearance on the Amu-Darya, Hubbi's mother, Ardvisura-Anakhita, appeared. She looked for the son crying for a long time. She both has built the first boat and has trained people in navigation to war at water. Thousand years she kept mourning, together with her weight the world even the underground demons cried. Then Hubbi's mother disappeared forever. According to the stories, earlier on a nose of courts by informers, the torso of the woman was represented. When Muslims came there, they cut down a face of a figurine. Since then at this figure the face is cut down and there were only two braids" [7., P.33].

Mother of Hubbi, Ardvisury-Anakhita ("Great mother", "The goddess mother") was the cult of fertility, the goddess of waters, representing the great water highway of Central Asia, the ancient Oks (Amu Darya) [Snesarev, 1969 p.243]. The women of Khorezm worshipped Anakhita as the Saint, the most popular patroness of fertility in oasis. They approached the river, did a sacrifice where there was a boat with the figurine of Anakhita [FDA-3]. Amu-Darya was especially attractive for barren women. In this regard, stories of old boatmen are as interesting as childless women in the past elected the vessels as the places for holding the ceremonies connected with Amu-Darya (Snesarev, 1969 p.246). Old dargha (a helmsman) told the vessel of Amu Darya: "When a boat (vessel) was at the coast, childless women rose by it and three times bypassed around a mast and beams which are sticking out in the boat, touching them. The helmsman gave them a patiya (blessing) and received flat cakes and scarfs; childless women, hoping to give birth in the future to the child, drank the water which has accumulated at the bottom of the vessel". (Snesarev, 1969 p.43) [FDA-4]

However, the main objective of the barren women was to get into a front-tip part of the vessel what boat-masters in every possible way interfered with. This results from the fact that the front tip of the vessel was considered forbidden, or tabooed. In this place, usually there was a helmsman only. This part of the vessel was strictly forbidden to be hit by something, and without the permission of the helmsman it was even impossible to go into that place which adjoins a nose. The sailors working at the vessel without trousers were obliged to put on them when they needed to approach to the front tip of the vessel. According to myths, this place of the vessel was devoted by their feast patron to the Biblical figure Saint Noah. However, the original reasons of it are deeper. The Amu Darya vessels differed in one feature: their nasal part (a basha), by old tradition, was made out of an original image. It was given the form of the human head, a mirror was located in the center, and from its sides two long braids weaved out of the horsehair overhung. Here, they beat small cloves a piece of a velvet with the coins sewed on it, and amulets. 'The boat nose resembled the human head very much' as the story-teller narrates, and 'when the vessel turned, it seemed that someone was turning the head'. According to some legends, the nose of the vessel represents Saint Noah's head. But, the most say that special decoration of a 'head' does not refer to anything specific. Such explanation is the result of dying off of religious representations in general. However, other interpretations take place and are transferred from generation to generation: a nose of the vessel represents the head the Ambar-ona (Snesarev, 1969 p.247) (mother Ardisury-Anakhita under the influence of Islam of the goddess of fertility in ancient Khorezm the image a sacred Ambar-ona "took shape") (Gorshunova, 2007 p.20). Among women, there is a ceremony in which barren women, having agreed with boatmen or fishermen, cross a 
watercourse moving to other coast of Amu-Darya, throwing sacrificial salt and bread into her waters and calling the patroness Ambar-ona, and take a patiya (blessing) from ticket collectors of the ferry. They are often transported by small boats and such magic crossings are made in the most various points through Amu-Darya. Especially crossings about Pitnyak (higher than Hazarasp) are famous where the tomb for Arandzha-bobo is found on a small island [FDA-5]. Moving through the Amu-Darya, women make ziyarat (pilgrimage) on the island, binding rags on a banner of a mazar (grave) and vowing to sacrifice a ram if they succeed in childbirth [FDA-5]. It has been a widespread belief among the women to stay on this island of children's souls, and they are allegedly shown to people from time to time.

In other cases, the women simplify a ceremony: they just come to the Amu-Darya coast and, without being transported to the other coast, make sacrifices to her waters throwing into them grain flat-cakes and salt. The same ceremony is one of the sacral actions known in Khorezm, when childless women step or jump through aryk (irrigation ditch) with the current water. Usually, it is made in the spring when new water of the Amu-Darya arrives to the canals of an oasis, and also is followed by a sacrifice to water (Snesarev, 1969 p.246).

In the ethnographic materials of Khorezm, including folklore, any bright mythological image didn't remain to idolize the Amu-Darya. Here, the domination of Moslem was too old. Therefore, it is necessary to address the ceremonial party of the Khorezm beliefs again to find any trace of this ancient cult. In the Islamic rule, there is a widespread belief that a person passes allegedly infernal tortures menacing to him if he/she crosses the Amu-Darya current seven times. Despite Muslim coloring, this belief goes back to an ancient cult of the Amu-Darya [5., P.238]. Most brightly honoring of the water of the Amu-Darya is noticeable in ceremonies of a sacrificial cult which differs in a variable ways and is made on the most various occasions. It is quite natural that such ceremonies take place at first in that community having the closest contact with the AmuDarya as the boatmen of the Amu Darya vessels who pass their whole life on the river or channels. The ceremony of sacrificing salt to the Amu-Darya water was very widespread though least difficult. The boatmen made it during sails to avoid allegedly "evil eye". The boatmen made also bloody sacrifices to the Amu-Darya. Before the next departure, after loading of the vessel, they brought a ram or other small cattle on it and cut it lowering blood in the water of the Amu-Darya [FDA-5]. Traditionally the boatmen threw the darga (the helmsman) into water at the time of descending a new vessel to the Amu-Darya for the first time. Similar to this ceremonial observation, the boatmen threw mirab (the water distributor) into water in case of start-up of the Amu Darya water to canals. It is difficult to establish roots of this custom with all reliability that there is a belief that dropping of a darg or mirab into the water are very late transformation of a sacrificial ceremony. (Snesarev, 1969 p.238) The solemn church services made in Khiva at the beginning of XX before the floods of the Amu Darya echoed ancient beliefs also. Ya. G. Gulyamov reports that the Muslim clergy organized a solemn procession to the island Aralcha-Auliya located on the lowered part of Tuya-muyun. There gathered all nobility of an oasis with gifts and sacrificial bulls.

Upon termination of their prayer they threw the sacrificed bull into the river as a victim to patron the spirit of the rivers. There are legends that the Khivan governor Allakulikhan $(1825-1842)$ has made a sacrifice of a bull at start-up of water through Tash-saka who is again constructed head constructions. The terrible and merciful Amu Darya was both a creator and a destructor of life and prosperity of the country and its inhabitants. (Mankovskaya, 1978 p.24)

At past, there were many ceremonies of propitiation of the Amu-Darya at which the victim was the livestock, in particular a bull or a ram. These ceremonies were the consequences of the 
representations of the sacral ceremonies of water elements, cult value of the Amu-Darya, and her concern with the idea of fertility. A special function of a sacrificial animal like a bull roots back to the totemic beliefs, and, later, close connection with the magic of the growth of plants and water traced at different stages in the history of religious beliefs. (Snesarev, 1969 p.238)

With the distribution of Islamic religion there were new stumps connected by Muslim ideology at the historical arena. The patron of waters of the Amu Darya Hubbi has turned in as historical Sultan Hubbi (Hubbi Hodge) the personality has entered hagiographical literature of Khorezm (Guliamov, 1957 p.33).The goddess of water and fertility Ardisuva-Anakhita has turned in protecting the sacred woman the Ambar-ona. On legends Sultan Hubbi was the son of the popular, Khorezm sheikh Hakeem ata(Suleyman Bakirgani), Anbar-ona was his wife whose second marriage was with other sheikh of Zengi-ata, is known on all average in Central Asia as the patron of shepherds (Snesarev, 1969 p.240). The legend about Hakeem-Ata and Ambar-ona is very popular among the population of Khorezm. However not the official Muslim version, but numerous national legends represent the most popular image of Ambar-ona as the Saint patronesses of women in the oasis. (Snesarev, 1969 p.240)

There are various legends about Hakeem-ata and his wife Ambar-ona and their sons. A legend was about historical Hakeem-ata, one of the sheikhs and propagators of Islam. The mystic Sufi sheikh was a wonder-worker, and married to the beautiful daughter of Burakhan, Ambar-ona having three sons: Askar, Mahmood and Hubbi (Sultan Ubbi, Hubbi-hodzha, Hubbi,). The eldest and the second one were their father's favorite sons while the youngest was Ambar-ona's favorite. At a test for obedience, Hubbi was late and at home only on the third call of mother, then it became clear that Hubbi was on the Amu-Darya and saved the perishing vessel in miraculous act a miracle. This event brought to the culmination of the old conflict between Hakeem-ata and the youngest son, and he would tell that Hubbi should leave the house. Hubbi was going to leave. His mother locked him in the room, yet he, having thrown off clothes and transforming himself into a pigeon, departed from the window of the house. After that he disappeared completely and is consequently considered as Goyib-bobo (disappeared granddad). (Snesarev, 1969 p.243, 258-259) [FDA-7]

According to another version of a legend, Hubbi plunged himself together with a bullock cart and horses into the depth of waters of the Amu Darya. It is believed that he is still alive there and time will come when he appears again. (Snesarev, 1983 p.62)

In the Hanka version, named after a district of Khorezm region, Sultan Hubbi appeared in the village of Durgadyk after having transformed himself into a pigeon. The legend says:

"Near Hubbi's house the tree grew, a bird flied to it and everything around was visible from top of the tree. The bird announced that "It is the good place, beautiful; it is possible to live here".

According to the legend, Sultan Hubbi was the bird which stopped in this place for a while. At that moment Anbar-ona, Hubbi's mother was drying wheat under the tree. The pigeon pecked a wheat grain, and the mother, failing to recognize her son, banished it, and he cautioned his mother by saying "Don't banish me with stones, your eyes will be filled with tears" and flied away. Hubbi, in the form of a pigeon, gives the idea of soul of the dead. Though the object of honoring disappeared, it is alive. (Mankovskaya, 1978 p.255) To other legends, Hubbi disappears in the Amu-Darya's water and becomes a lord of the underwater world. He regulates the mode of the river, feeding the Khorezm oasis, fighting against the spirits causing floods of undercurrents, the aranglara (Dzhabbarov, p.252). 
The informant from Khanka, who has worked on the Amu Darya vessels for forty six years, tells:

"The help is given to the vessels by Sultan Hubbi on the river. When there is a disaster in the vessel, helmsmen address him and he helps. The seamen offer sacrifices to Sultan Hubbi and other Saints. During natural disasters like floods when it filled the villages, he, Sultan Hubbi fought against a wrangler and spoke to them: "Clean water!" and underwater spirits submitted to him. (Guliamov, 1957 p.33)

Sultan Hubbi had very interesting predecessors, ideas of whom were kept by the ethnography of Central Asia. Their images go back genetically to much earlier stage of an embodiment of water elements. Such a water spirit is Sochli-ata ("the hairy father"). The owner of the underwater world, grazing fish herds, is Hubbi's image, and in beliefs of the Uzbeks in Khorezm, he was a feast patron of fishery. Unlike many other patrons the feast of fishers in Khorezm has distinctly kept ancient pre-Muslim lines: he is not the patron saint, but the mythical living being dwelling in the water and grazing herds of fishes there. (Snesarev, 1969 p.327-328)

D.Freyser who convincingly proved connections of these images with nature, almost didn't disclose motive of the water in this complex though it is distinctly traced in the myths and ceremonies devoted to Osiris, Tammuz, Adonis and other companions of Great gods researched by him. (Snesarev, 1969 p.253)

\section{Channels}

The economy of Khorezm is always dependent on mechanical irrigation. Economy determines the corresponding form in the field of ideology, and, in this case, in the field of hagiology: the manmade channels taking water from the Amu Darya are purchased by patrons on behalf of a number of the Khorezm Saints. Ideas of deities and spirits were once connected with the water of many channels of and they were replaced by Muslim Saints.

Since ancient times the water arriving on channels, especially on fields of Khorezm, is taken as sacred. Here, to my opinion, it is necessary to pay attention to one very essential phenomenon (Snesarev, 1969 p.253). Almost all main channels of Khorezm playing a large role in the economic life of an oasis are connected with a name of the Saints. Such Saints are sometimes esteemed as the patrons of the channels, and also called as their direct founders.

A classic example is that Saint Palvan-ata (Pahlavan Mahmoud) (Snesarev, 1983 p.43), the national hero, wrestler and poet (Snesarev, 1983 p.106), patron of Khiva, allegedly created the main channel wonderfully which received his name afterwards respectively. This version was created contrary to paradoxical temporary discrepancy: the legend was widely adopted not earlier than the $14^{\text {th }}$ century when there lived historically quite a real "Saint", the patron of Khiva for many centuries after the valid construction of the channel. The legend of the city of Khiva's cartridge, Palvan-ata which, passing from the coast of the Amu-Darya towards Khiva, drew the staff on the widespread ground and after it, the line stretched after him and the ready channel called by the name of Palvan-ata (Snesarev, 1983 p.43).

Precedents to a legend of Pakhlavan Mahmoud speak about sacral communication of Saints with water. Almost similar legend about wonderful burrow through the channel is connected with a name of the Saint Sheikh Husim-bobo from the Hazarasp district in Khorezm. Vicinities of Taxta, the city in Turkmenistan, were flooded allegedly through channel by Khan-yab Saint Ismamutata* (Snesarev, 1983 p.43) (Isim, the son Musaiba) funeral yard which was read in this area on ruins of the ancient settlement carrying the name Eshrat-kala (the city in Turkmenistan). Saint 
Suleyman (Tomb near the village Madir, Xonqa district) was considered as the patron of linkage of channels to the south of Khanka; the prayers were organized at his grave when there was not enough water in the channels. There was a proverb "If ask water, ask from Suleyman!" [FDA-8] Shabbaz-bobo [FDA-9] channel was on the right coast of the Amu-Darya as the bearer of water on fields, the funeral tomb which was about Kyat as the breakup was esteemed town Biruniy. The linkage of channels near Gurlen has resulted from the "miracles" made by local Saints (Snesarev, 1983 p.184).

Among the people the legend about the channel Gaziabad* (Snesarev, 1983 p.44) who would leak through Kushkupyr district, is widespread and connected with the evil spirits of Aranga. The legend says that once the Amu Darya had risen so much that it flooded the coast of the Gaziabad channel and the village's with their crops. According to the legend, this situation was connected with the fact that Aranga (evil spirits) was angry with people and declared a war against them. The people were in panic and didn't know what to do. One leading mullah who realized all complexity of the situation took a sword and climbed down the mountain directly to the river. When he went into the awful raging waves, people waited for what would occur further, and suddenly water in the channel calmed down and began to flow quietly. But, the water reddened, and the blood-stained body of a patron mullah emerged on the surface. In another legend, water in the channel calmed down as a result of fight between Ishan, patron of mullahs, and Aranga. Being considered as the evil forces directed against people, Arangi did not always win and sometimes became powerless in front of the mind and insight of the human being. This channel was named after Gaziabad in honor of a heroic act of the Ishan (Dzhabbarov, 2014 p.36-37).

\section{Conclusion}

In conclusion, it is possible to repeat once again: neither a person, nor society is inconceivable without the idea of sacral, both in individual consciousness and in collective unconscious. Studying sacral geography moves us to the answer to the central issue of the worldview: whether overcoming nature is the unique vector of the development of a civilization or not. The tradition of considering nature as means of achieving social, economic or political goals is threatened with the degeneration of not only nature but also the humans and their future.

Thus, the stated materials give attest to the claim that the elements of ancient water cult as a component entered the religious practice of the people of the Khorezm oasis. Honoring of natural places, Saints of whom people ask for help and protection, and the legends connected with mysterious places of their rest are an inseparable part of the traditional culture of the people of Khorezm. It connects the past and the present in a thread.

\section{Notes}

* Our article covers a wider area than the modern geographical concept of "Khorezm region" which includes the territory of the Republic of Karakalpakstan and Turkmenistan, which were parts of ancient Khorezm and Khiva Khanate.

* Isym lived at the time of the Prophet Muhammad, and his father-Musaib Gases became famous as a commander, "Army of Islam", participating in many battles for the Muslim faith. 
* Gazi in the past - the fighters for the faith, and later - just died a violent death. [6.P.44]

\section{References}

Dzhabbarov Isa. 2014. Ancient Khorezm: A country of high culture and a unique spirituality (Ethno-historical essays). M .: IEA RAS, p. 304 (in Russian)

Mankovskaya L.Yu, Bulatov V.A. 1978. Monuments Khorezm architecture. Tashkent. "Gafoor Ghulam", p.192 (in Russian)

Dzhabbarov Isa. 1968. Secrets of ancient ruins. T.: "Uzbekistan", 1968. p. 188 (in Uzbek)

Avesta. Selected Hymns. 1990. Translation from Avest an and comments, prof. I.M. Steblin-Kamensky. Dushanbe .: "Adib", p. 176 (in Russian)

Snesarev G.P. 1969. Relics of pre-Islamic beliefs and practices in Khorezm Uzbeks. M.: Science, p. 369 (in Russian)

Snesarev.G.P. 1983. Khorezm legends as a source on the history of religious cults of Central Asia. M.: Science, p. 213 (in Russian)

Guliamov Ya.G. 1957. History of Khorezm irrigation. From ancient times to the present day. Ans. Ed. Acad. S.P.Tolstov. T.:"Uzbek SSR Academy of Sciences". p. 313 (in Uzbek)

Valyanskaya, O.P.1992. Woman in myths and legends. Ed. O.P.Valyanskaya. Encyclopedic Dictionary. Tashkent, "Qomus", p. 192 (in Russian)

Gorshunova O.V. 2007. Female deities in the system of religious and philosophical ideas of the peoples of Central Asia Author. dis ... Doctor historical Sciences. M. p. 50 (in Russian)

\section{Field data of the author:}

FDA-1. Urgench district, village Karaul, March 2016.

FDA-2. Khorezm region. Khiva, Khazarasp, Xonqa district. 2015-2016 year.

FDA-3. Khazarasp district, village Pitnyak in December 2016.

FDA-4. Xonqa District, village Tomadurgadik, Inf. Vafaev Bobojon. September 2016.

FDA-5. Khazarasp district, village Yangibazar, Pitnyak august 2015. March 2016 .

FDA-6. Urgench district, village Cholish April 2016.

FDA-7. During field studies in Khorezm we found that in the region there are more than 50 places of pilgrimage associated with the name and Hubbi Goyib Bobo (who escaped). In Xonqa district, in the village of Durgadyke, Khorezm region have been called Mazar Sulton Hubbi and the local population believe in his disappearance from the place.

FDA-8. Xonqa district, village Madir. October 2016.

FDA-9. The tomb in the town of Beruni, Karakalpakstan. March 2016.

FDA-10. May 2016, Beruni district of Karakalpakstan, the tomb Sulton Uwais.

FDA-11. Khiva district, village Badirhan., Ichan-kala mausoleum Pakhlavan Mahmoud. September 2016. 